\title{
TRANSLATION TECHNIQUES ON INDONESIAN SWORN TRANSLATOR'S LEGAL TEXTS TRANSLATION
}

\author{
Aris Wuryantoro, H.D. Edi Subroto, M.R. Nababan \\ Postgraduate Program Sebelas Maret University, Surakarta \\ allaam_71@yahoo.co.id
}

\begin{abstract}
Legal translation is the transferring the meaning from source language text into target language which not only consists of language system but also legal system. This research aims to analyze the translation techniques used by the Indonesian sworn translators in translating legal texts from English into Indonesian. This research uses descriptive qualitative method. Data obtained through content analysis on translations of the Indonesian sworn translators containing Certificate of Live Birth, Certificate of Marriage, Principles Statement of Terms and Conditions. The result of the research reveals: a) single translation technique dominates the translation technique in translating legal and law scientific texts from English into Indonesian obtains $(66,67 \%)$ data consisting of 10 variants (literal, amplification, recognized, reduction, borrowing, modulation, transposition, adaptation, colque, and description); b) couplet translation technique (32,\%) data consisting of 16 variants (literal and borrowing, literal and recognized equivalent, literal and reduction, literal and adaptation, literal and amplification, literal and transposition, literal and modulation, literal and colque, borrowing and amplification, literal and description, borrowing and modulation, borrowing and adaptation, borrowing and transposition, modulation and colque, reduction and colque, and reduction and adaptation), and triplet translation technique $(1,19 \%)$ data consisting of 4 variants (literal + borrowing + modulation, literal + amplification + transposition, literal + amplification + borrowing, and literal + transposition + reduction). Researcher concludes that translation technique of legal texts from English into Indonesian conducted by Indonesian sworn translators contains three kinds of translation techniques, i.e. single translation technique, couplet translation technique, and triplet translation technique with 30 variants.
\end{abstract}

Keywords: legal text, law scientific text, translation technique, sworn translator

\section{Introduction}

Globalization is happening during this indicate interplay between one country and another. In this globalization has spread values , concepts, and laws from around the world to various parts of the world. Globalization is also accompanied by a process of globalization, where local values (political setting and context) were taken from one place to another (Benda-Beckman et. al, 2005:8). Thus, globalization started from interplaying in abstract forms (values and concepts) gradually becomes real (legal system), which originated from the local values and concepts into international values and concepts that eventually become international law.

Merry in Irianto (2012:160) states that globalization is not only indicated by the borderless state but also the borderless law. It shows that the law of a particular region can penetrate into other areas indefinitely. International and transnational law can penetrate into the territory of any country, even the local area anywhere in the grassroots. 
Otherwise, it is not impossible if the law and the principles adopted in part or entirely locally becomes international law.

Each legal system has a vocabulary that is closely related to the concept, regulation and function of the law on its people in use. David and Brierly (1985:19) state that each legal system has a vocabulary used to express concepts, its rules are arranged into categories, it has techniques for expressing rules and interpreting them, it is linked to a view of the social order itself which determines the way in the which the law is applied and shapes the very function of law in that society.

\section{Method}

This research uses descriptive qualitative study with a single case. Sutopo (2002:112) reveals that the research referring to single case study, where the study focused on one characteristic. Based on the above opinion, this study is a single case study because it only focused on a single goal, namely the translation.

Sources of data in qualitative research can be a human, and behavioral events, documents and archives as well as a variety of other objects (Sutopo, 2002:50-53). Legal text is the source of the data in this study includes: a) legal documents are Principles Statement of Terms and Conditions, and b) personal documents are Certificate of Live Birth and Certificate of Marriage.

\section{Result and Findings}

Based on the analysis of data, researcher gets the data 674 which has three types of translation techniques. The translation techniques are: a) single translation technique has 450 data (66. 67\%); b) couplet translation technique has 216 data (32. 14\%); and c) triplet translation technique has 5 data (1, $19 \%)$.

\section{Single Translation Technique}

Single translation technique refers to only one translation technique used by the translator. From 450 finding data, there are 10 variants of single translation technique. This technique consists of: literal has 245 data (54. 44\%), amplification has 43 data (9. 56\%), recognized equivalence has 35 data (7. 78\%), reduction has 33 data (7.33\%), borrowing has 27 data (6. 00\%), modulation has 20 data (4. 44\%), transposition has 19 data (4. 22\%), adaptation has 12 data (2. 67\%), calque has 9 data (2.00\%), and description has 7 data (1. $56 \%)$.

Translator literally translates words such as Bride, Witness, and Name into Pengantin perempuan, Saksi, and Nama. Besides, translator also translates phrases Certificate of Marriage and Company Name translated into Akta Perkawinan and Nama Perusahaan. Word equivalences which form phrases strictly refer to the source language words but word constructions have been adapted to the target language phrases (phrases in Indonesian). The English noun 
phrase construction, head + modifier or modifier + head changes into Indonesian noun phrase construction, head + modifier. Translator uses this method in order to avoid meaning distortion in the target text language. A noun phrase which has two same words will be different if the position of words in different place. For example, the phrase company name translated into nama perusahaan will be different meaning if the position in the same place of language construction, perusahaan nama (the company which produces name).

Translator uses amplification technique to translate holiday pay, sickness absence, and civil libertarians into liburan yang dibayar, kemangkiran kerja karena sakit and penganut paham kebebasan sipil. Each phrase gives explanation of terms' function and meaning in its translation. This technique makes the reader will be easier in understanding the translation text. Recognized technique used by the translator to translate terms and conditions, breaking the law, and binding legal force into syarat dan ketentuan, pelanggaran hukum and kekuatan hukum yang mengikat. Terms of syarat dan ketentuan, pelanggaran hukum and kekuatan hukum yang mengikat are recognized by translators as the equivalences of terms and conditions, breaking the law, and binding legal force.

Translator applies reduction technique to translate the fact of birth, a particular qualification, and the completion of a 6 month probationary period into kelahiran, kualifikasi and masa percobaan 6 bulan. Phrase the fact of birth translated into kelahiran is less impact on the accuracy of the translation when compared to masa percobaan 6 bulan.

Borrowing technique used by translator to translate postcode and moral standards into postcode and standar moral. There are two types of loan translation techniques used by translator, pure borrowing and borrowing with spelling adjustments in the target language.

Translators uses modulation technique to translate Overtime payments are made in line with the Company Remuneration Policy into Pembayaran uang lembur akan dilakukan sesuai dengan Kebijakan Remunerasi Perusahaan. Translator takes this technique to adjust the equivalence of meaning in the context of sentence. Overtime payment will be naturally translated into pembayaran uang lembur than pembayaran lembur.

Transposition technique applied by the translator to translate a satisfactory standard, addiction, and it serves into memuaskan, kecanduan narkoba and dijalankan. There are three types of translation transposition techniques applied by translators in translating words or phrases mentioned above. In $a$ satisfactory standard translated into memuaskan, there is a transposition from phrase to word. Otherwise, translation of addiction translated into kecanduan narkoba, it takes transposition from word to phrase. On 
the other hand, translation of it serves translated into dijalankan, there is transposition from active sentence into passive voice.

Translator implements adaptation technique to translate dear, bridegroom and your sincerely translated into Yth (shortened for Yang terhormat), mempelai pria and hormat saya. Dear literally means beloved or precious translated into Yang terhormat. Translator adapts the target cultural elements in translating such words and phrases.

Translator uses colque technique to translate to solemnize marriage, it will terminate on and inquiries to into untuk mengesahkan perkawinan, kontrak akan berakhir pada tanggal, and pertanyaan untuk. Words, phrases, and clauses are translated literally in both lexical and structural according to the source language.

Description technique used by translator to translate any unauthorized person into siapapun yang tidak wewenang untuk itu and libertarian into seseorang yang meyakini bahwa setiap orang harus diberikan hak untuk melakukan atau menyampaikan kehendaknya tanpa adanya hambatan dari pemerintah. Translator tries to describe the meaning of the term clearly in order to avoid multiple interpretations for the target language text reader.

\section{Couplet Translation Technique}

There are 219 data of couplet translation technique which consists of 16 variants: literal and borrowing are 146 data (66. 66\%), literal and recognized equivalent are 15 data $(6.85 \%)$, literal and reduction are 14 data (6. 39\%), literal and adaptation are 10 data (4. 56\%), literal and amplification are 7 data (3. 20\%), literal and transposition are 7 data (3. 20\%), literal and modulation are 5 data (2. 28\%), literal and colque are 4 data (1. $82 \%$ ), borrowing and amplification are 4 data (1. 82\%). Literal and description, borrowing and modulation, borrowing and adaptation, borrowing and transposition, modulation and colque, reduction and colque, reduction and adaptation, each of these couplet techniques has 1 data $(0.46 \%)$.

Translator uses literal and borrowing techniques to translate department of health, county of birth and concept of law into departemen kesehatan, county kelahiran and konsep hukum. Translator literally translates health, birth, and law into kesehatan, kelahiran and hukum. On the other hand, translator uses borrowing technique to translate department, county, and concept into departemen, county and konsep. Translator uses borrowing technique both in pure borrowing and borrowing with spelling adjustment.

Translator applies literal and recognized equivalence techniques to translate Principle Statement of Terms and Conditions into Pernyataan Pokok Syarat dan Ketentuan. Translator literally translates principle statement into pernyataan pokok, while 
recognized equivalence applied to translate terms and conditions into syarat dan ketentuan.

Translator applies literally and reduction techniques to translate You are obliged to give the Company (notice) weeks notices to terminate will be made permanent into Anda berkewajiban untuk menyerahkan kepada Perusahaan (Pemberitahuan) minggu sebelumnya untuk mengakhiri kontrak kerja Anda. The word permanent in to terminate will be made permanent is not translated or reduced because of perceiving lack of information contributed to or been sufficiently represented by a word which also means to end permanently, while other elements of the sentence are translated by using literal technique.

Translator uses literal and adaptation techniques to translate Signature of Celebrant, Date filled by the Registrar and Dear (Name). Translator literally translates signature, date and name into tandatangan, tanggal and nama. Translator, however, uses adaptation technique to translate celebrant, registrar and dear into pendeta, pencatat and kepada Yth.

Translator applies literal and amplification techniques to translate breach of confidentially and any sickness absence into pelanggaran terhadap ketentuan kerahasiaan and setiap ketidakhadiran kerja karena sakit. Translator literally translates breach and any into pelanggaran and setiap. On the other hand, translator applies amplification technique to translate word confidentially and phrase sickness absence translated into ketentuan kerahasiaan and ketidakhadiran kerja karena sakit. Translator applies amplification technique in order to provide more complete information to the target reader.

Translator uses literal and transposition techniques to translate: At the end of this period if your performance is satisfactory standard of your appointment will be made permanent into Pada akhir periode, apabila kinerja Anda memuaskan, Anda akan diangkat menjadi permanen. Translator uses transposition technique, transposition of phrases become words, your appointment and satisfactory standard translated into Anda and memuaskan. Besides, translator literally translates the other words in this sentence.

Translator uses literal and modulation techniques to translate overtime payments into pembayaran uang lembur. There is modulation technique in overtime translated into uang lembur, yet translator literally translates payment into pembayaran.

Translator uses literal and colque techniques to translate signatures of parties to the marriage into tanda tangan para pihak pada perkawinan. Translator literally translates signatures into tanda tangan. Translator, however, uses colque technique to translate the parties to the marriage into para pihak perkawinan. Therefore, the translator uses literal and colque techniques in 
translating signatures of parties to the marriage to tanda tangan para pihak pada perkawinan.

Translator applies borrowing and amplification techniques to translate this copy serves as prima facie evidence of the fact of birth in any count proceeding into salinan dokumen ini merupakan bukti yang bersifat prima facie terhadap kelahiran dalam proses pengadilan manapun. Translator applies pure borrowing in translating prima facie. However, translator applies amplification technique in translating evidence into bukti yang bersifat. It means that translator applies borrowing and amplification techniques to translate prima facie evidence into bukti yang bersifat prima facie.

Translator uses literal and description techniques to translate Signature of Celebrant becomes Tanda tangan Pihak yang menyatakan di atas. Translator literally translates signatures into tanda tangan. Translators, however, uses description to translate celebrant into pihak yang menyatakan di atas. This technique takes in order to provide more complete information to the target text reader.

Translator uses borrowing and modulation techniques to translate at the end of this period if the performance is of a satisfactory standard will be your permanent into pada akhir periode tersebut, apabila kinerja Anda memuaskan, Anda akan diangkat menjadi permanen. There is modulation in clause of your permanent will be permanent because of shifts in the viewpoint of translator to the source language text. Translator uses borrowing with spelling adjustment in translating permanent into permanen.

Translator applies borrowing and adaptation techniques to translate Dear (name) to Yth (name). Dear lexically meaning lover or beloved, is translated into Yth (shortened from Yang terhormat). Translator adapts the target cultural element to translate Dear. On the other hand, translator applies pure borrowing to word name.

Translator uses borrowing and transposition techniques to translate it is a condition of your employment that the company is satisfied on your medical fitness to carry out your duties into yang menjadi persyaratan kepegawaian Anda adalah perusahaan menerima bahwa Anda sehat secara medis untuk melakukan tugas-tugas Anda. Translator uses borrowing with spelling adjustment to translate medical into medis, yet translator uses transposition, from adjective becomes verb, in satisfied into menerima.

Translator applies modulation and colque techniques to translate I...having authority under the Marriage Act 1961 to solemnize marriage into Saya...yang memiliki wewenang berdasarkan Undang-Undang Perkawinan 1961 untuk mengesahkan perkawinan. Translator uses modulation technique to translate solemnize, lexically meaning hold, into mengesahkan (legalize). It 
means that there is a different viewpoints of translator to the source language text.

Translator uses reduction and colque techniques to translate hereby certify that I have this day at... into dengan ini saya menerangkan bahwa pada hari ini... Translator reduces word $a t$ in this clause and uses colque to translate that I have this day at... into bahwa pada hari ini... It can be said that translator uses reduction and colque techniques in translating the clause above.

Translator uses reduction and adaptation techniques in translating Dear (Name) into Yth (shortened from Yang terhormat). Translator adapts the source cultural element in the target text in Yang terhormat, meanwhile, translator reduces the word name.

\section{Triplet Translation Technique}

There are 8 data in triplet translation technique which has 4 variants, namely: literal, borrowing and modulation techniques are 3 data (37, 50\%); literal, amplification and transposition techniques are 3 data $(37,50 \%)$; literal, amplification and borrowing are 1 data (12, 50\%); and literal, transposition and reduction techniques are 1 data $(12,50 \%)$.

Translator uses literal, borrowing and modulation to translate This appointment is conditional on a satisfactory Occupational Health Service/Company Doctor into Pengangkatan Anda dilakukan dengan syarat penilaian Dinas Kesehatan Kerja/Dokter Perusahaan yang memuaskan. Translator literally translates Occupational Health Service into Dinas Kesehatan Kerja. On the other hand, translator uses borrowing with spelling adjustment to translate doctor into dokter in phrase Dokter Perusahaan. Translator, however, applies modulation technique to translate is conditional on a satisfactory into dilakukan dengan syarat because of shifting in the meaning contained in the phrase.

Translator uses literal, amplification and transposition techniques to translate any alternations invalidate this certificate into pengubahan apa pun akan membuat akta kelahiran ini tidak berlaku. Translator literally translates any alternations into pengubahan apa pun, yet there is amplification technique in translating word invalidate into akan membuat tidak berlaku. On the other hand, translator uses transposition to translate certificate into akta kelahiran, word changes to phrase. It means that translator translates any alternations invalidate this certificate into pengubahan apa pun akan membuat akta kelahiran ini tidak berlaku by using literal, amplification and transposition techniques.

Translator applies literal, borrowing and amplification techniques to translate Lawyer's Conception of Law into Konsepsi Hukum di mata Pengacara. Translator literally translates Law into Hukum, yet translator applies borrowing with spelling adjustment in translating conception into konsepsi. Meanwhile, translator applies amplification 
technique to translate Lawyer's into di mata Pengacara. Translator takes this technique in order to provide more complete information to the target reader.

Translator applies literal, transposition and reduction to translate we wish to define law by two "moment" - that of the order and that of coercion into hukum didefinisikan melalui dua “peristiwa”-terkait keteraturan dan paksaan. Translator literally translates law into hukum. While transposition technique used by translator to translate to define becomes didefinisikan, there is shifting from active into passive voice. Translator reduces clause we wish to define law ... into hukum didefinisikan...

\section{Conclusion}

Translation technique of legal texts and legal scientific texts from English into Indonesian conducted by Indonesian sworn translator obtains 674 data which includes three kinds of translation techniques: single translation technique which consists of 10 variants has 450 data (66. 67\%); couplet translation technique which consists of 16 variants has 216 data (32. 14\%); and triplet translation technique which consists of 4 variants has 8 data (1. 19\%).

\section{References}

Baker, M. 1992. In Other Words: A Course book on Translation. London: Sage Publication.
Benda-Beckmann, F. von, K. Von BendaBeckmann and A.Griffiths. 2005. Mobile People, Mobile Law: Expanding Legal Relations in A Contracting World. Aldershot \& Burlington: Ashgate.

Buckland, M. K. 1998. What is a "documents?" in http://people.ischool. berkeley.edu/ buckland/digdoc.html (August 10, 2013).

David, Rene and John Brierly. ( $3^{\text {rd }}$ Ed). 1985. Major Legal System in the World Today. London: Stevens.

Irianto, Sulistyowati. 2012. Pluralisme Hukum dalam Perspektif Global: Kajian Sosio-Legal. Denpasar: Universitas Indonesia Press.

Larson, M. L. 1984. Meaning-Based Translation: A Guide to Cross Language Equivalence. Lanham: University Press of America.

Molina, Lucia and A. H. Albir. 2002. "Translation Techniques Revisited: A Dynamic and Functionalist Approach". Meta: Translators' Journal. vol. 47, no. 4 , pages. $498-512$.

Newmark, P. 1988. A Text Book of Translation. Herfordshire: Prentice Hall.

Nida, E. A. 1964. Towards a Science of Translating. Leiden: E. J Brill.

Sarcevic, Susan. 1997. New Approach to Legal Translation. The Hague, Netherlands: Kluwer Law International.

Simms, Karl.(ed).1997. Translating Sensitive Texts: Linguistic Aspects. Amsterdam: Rodopi.B. V

Suryawinata, Zuhridin and Sugeng Hariyanto. 2003. Translation: Bahasa Teori dan 
Penuntun Praktis Menerjemahkan. Jakarta: Kanisius.

Sutopo, H. B. 2002. Metodologi Penelitian Kualitatif. Surakarta: Sebelas Maret University Press.

Wiber, M.G. 2005. "Mobile Law and Globalization: Epistemic Communities
Versus Community-Based Inovation in The Fisheries Sector". In F. von Benda-Beckmann, K. Von BendaBeckmann and A. Griffiths. 2005. Mobile People, Mobile Law: Expanding Legal Relations in A Contracting World. Aldershot \& Burlington: Ashgate. 